\title{
Importance of the principles of criminal law in the classification of crimes
}

\author{
Konstantin Aleksandrovich Volkov ${ }^{1}$, Vladimir Valerievich Agildin ${ }^{2}$, and Bulat \\ Umerzhanovich Seitkhozhin ${ }^{3}$ \\ ${ }^{1}$ Far Eastern Branch of the Federal State Educational Institution of Higher Education Russian State \\ University of Justice, Khabarovsk, Russia \\ ${ }^{2}$ Federal State Budgetary Educational Institution of Higher Education Baikal State University of \\ Economics and Law, Irkutsk, Russia \\ ${ }^{3}$ Scientific Research Institute of Economic and Legal Researches of Karaganda Economic University, \\ Karaganda, Kazakhstan
}

\begin{abstract}
The correct qualification of a crime provides the basis for achieving the goals of criminal liability, including sentencing a just punishment. During qualification, law enforcement agencies (investigative bodies, inquiry bodies, and court) often face problems caused by contradictions in criminal law regulation (a gap in law, defects in law, legal conflicts, evaluation categories of law, etc.). According to the authors, it is possible to eliminate the contradictions of criminal law regulation by applying the principles of criminal law as a direct regulator of criminal law relations. Purpose of the research: to identify the problems of qualifying crimes in the modern practice of preliminary investigation bodies and courts, as well as to determine the place and role of the principles of criminal law in the process. Framework of the research. The research was carried out with general scientific methods (dialectical, statistical, comparative legal); in addition, methods of analysis, deduction, synthesis, as well as a formally legal method, were used in the research. Conclusions: the authors draw the conclusion that the principles of criminal law should be considered as an independent fundamental form of Russian law.
\end{abstract}

Keywords: qualification of crime, principles of law, delimitation of crimes, legal understanding

\section{Introduction}

Many foreign and Russian scholars seem to rely on legal positivism in legal science. The above fully applies to criminal law including the qualification of a crime, the study of both theoretical and practical problems of law enforcement in the area of criminal proceedings. Thus, when the concept of "qualification of a crime" is considered, it is normally stated in legal science that it is the establishment of the correspondence (identity) between a specific socially dangerous act and the redistributed criminal law provision stipulated for in the criminal law.

\footnotetext{
* Corresponding author: volkovka@ mail.ru
} 
Based on this circumstance, scientists conclude that in qualifying a crime, the criminal law provision described directly in the Special Part of the Criminal Law is applied. At the same time, the answer to the question of how to establish such an identity in the presence of contradictions in criminal law regulation caused by gaps in criminal law, defects in criminal law, legal (interethnic, inter-sectoral, intra-sectoral) collisions, evaluative categories of criminal law, etc. remains outside the scope of the research. Normally, this leads to difficulties for law enforcement officers in assessing a criminal act, and as a consequence, to errors in the qualification of crimes. Most importantly, this subsequently leads to the wrong qualification of crimes and the unfair imposition of punishment.

\section{Results}

Contemporary criminal law is faced with challenging times. Chaotic changes in the existing criminal law shape a new criminal law reality and criminal law policy that requires an updated paradigm [1]. Today, it can be stated that many amendments to the criminal law, which mostly lack objective grounds, have become a modern negative feature of the criminal law policy. At the same time, no one denies the fact that the criminal law as a codified regulatory document should not become a frozen dog-ma and requires certain adjustments, whenever required. However, any amendments should be due to objective changes in the living conditions, as well as qualitative and quantitative changes in crime in the country [2]. In this regard, Robin Duff rightly argues that the world is facing a crisis of overcriminalisation as criminal law has be-come chaotic, unprincipled, and overly expansive [3].

Against the background of a decrease in the key macroeconomic indicators, an increase in social stratification in the country, and other negative trends of a socio-political nature, the crime rate has continued to decline in the country since 2007. At the end of 2019, 2,024,000 crimes were registered (1.6\% higher than in the same period last year). The proportion of grave and especially grave crimes is $24-25 \%$. Ac-cording to Nomokonov, one can see a certain paradox since it was with such figures that from the end of the 1980s of the last century until 2006, there was a tendency for an increase in crime. If in 2006 the crime rate in Russia per 100,000 of the population was 2,695 crimes, then in 2018 this figure fell to $1,360[4]$.

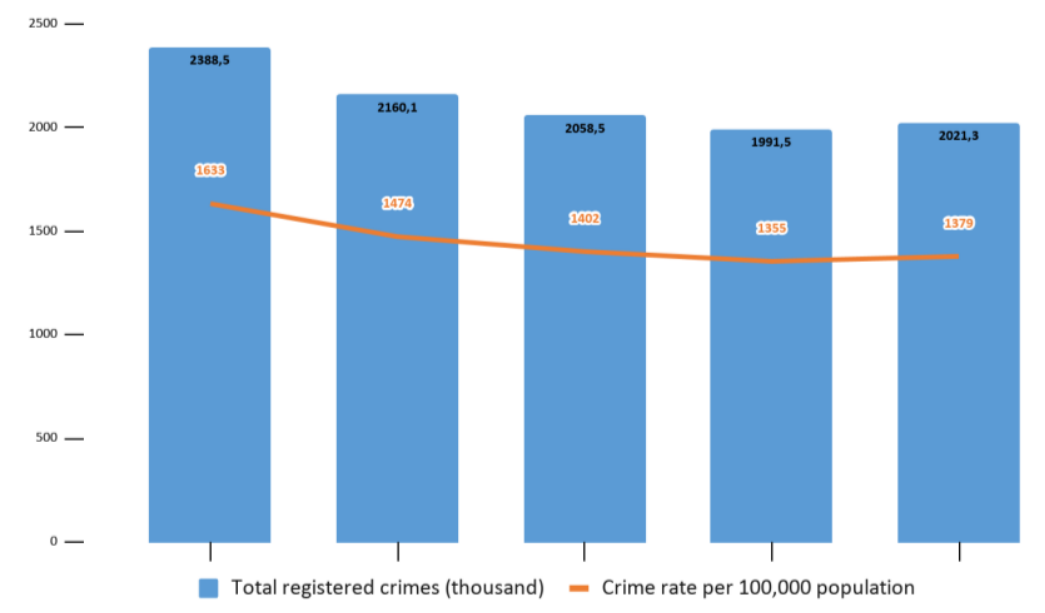

Fig. 1. Registered crimes (thousand). Dynamics and crime rate. 
Against the background of the absence of any objective prerequisites for changes in the criminal law, from January 1997 to September of this year, the Federal Assembly of the Russian Federation adopted 255 draft laws concerning over three thousand amendments to the criminal law. Two-thirds of the novels were aimed at criminalising criminal acts, which cannot but affect the effectiveness of the law enforcement activities of the preliminary investigation bodies and the court, since their activities are accompanied by constantly updating the scope of the criminal and the punishable [5].

There is no denying those authors' speaking about the ever-lowering quality of the text of the criminal law. In this regard, Patrick Tomlin reasonably calls for the search for a more effective mechanism to protect society from any excessive criminalisation by the state [6]. The analysis of the issues of qualification of crimes and problems associated with the presence of contradictions in criminal legal regulation shows that the principles of law are one of the actual regulators of social relations and ex-press the fundamental means of legal regulation in the criminal legal assessment of the offence.

\section{Discussion}

The concept of "qualification of a crime" and "principles of criminal law" are part of more general concepts like "crime", "qualification", and "principles of law"; then, consequently, they include in their content not only specific traits caused by ap-plying the principles in qualifications of crimes but also signs of those generic concepts.

In contemporary criminal law literature, the qualification of a crime is usually understood as the establishment of correspondence (or identity) between the signs of a committed socially dangerous act and the body of a crime provided for by the Special Part of the Criminal Law. By giving a generalised definition of the term qualification of crimes, Kurinov understood it as "a conclusion about the similarity (identity) of a specific life case - a crime - to the concept of a crime of that type that is stated in the provision of the criminal law" [7]. In correctly drawing attention to the fact that the tool for qualifying a crime is the corpus delicti, the famous Russian scientist Kudryavtsev clarified this term by saying that the qualification of a crime is "the establishment and legal consolidation of the exact correspondence between the signs of the committed act and the signs of the corpus delicti provided for by the criminal law provision" [8].

The authors believe that Gaukhman, who in his monography with the same name defined the qualification of a crime as "the establishment and legal consolidation of the exact correspondence between the actual signs of the committed act and the elements of the corpus delicti provided for by the criminal law, as well as other laws and (or) other regulatory legal acts, references to which are contained in the blanket dispositions of the articles of the Special Part of the Criminal Code of the Russian Federation" [9].

It seems that qualifying crimes is characterised by the important features as follows: law enforcement nature, socio-psychological mechanism, and judicial personality. Thus, the qualification of a crime is to establish and legalise the exact correspondence between the actual signs of the committed act and the signs of corpus delicti within the framework of the law enforcement activities of the competent authorities in the criminal proceedings.

In the criminal law literature, the focus has been continually on the need to ap-ply the principles of criminal law in assessing criminal legal acts [10].

Currently, the existing criminal law contains five principles of criminal law: legality (Article 3 of the Criminal Code of the Russian Federation), equality of citizens in the eyes of the law (Article 4 of the Criminal Code of the Russian Federation), guilt (Article 5 of the Criminal Code of the Russian Federation), justice (Article 6 of the Criminal Code of the Russian Federation)) and humanism (Article 7 of the Criminal Code of the Russian Federation). 
In analysing the philosophy of criminal law, the overwhelming majority of au-thors understand it as an exhaustive list of basic provisions established by law [11]. It seems that the philosophy of criminal law is not just a set of fundamental provisions of criminal law provided for by the criminal law, its elements (individual principles) are interrelated and interdependent, which makes it possible to maximise the goals and objectives of criminal law including when qualifying crimes.

Unfortunately, the existing criminal law does not define the term "principles of criminal law". As a result, in contemporary legal literature, the principle of criminal law is defined as "beginnings", "foundations" of "ideas", "provisions" that define the essence of criminal law as a branch and, by virtue of legal consolidation, have a generally binding significance. According to Blinnikov, the principles of criminal law are "the fundamental principles and guiding ideas that determine the content and direction of state activities in the field of combating crime" [12]. Matveeva defines the principles of criminal law as "the main provisions, basic principles and governing ideas that determine the content of criminal law, on the basis and in accordance with which the basic institutions and provisions are built and applied" [13].

In this regard, it is necessary to mention the reasonable opinion of Ershov regarding the narrowness of this approach, which is characteristic of legal positivism, which ultimately limits the law exclusively to the provisions of law established by rule-making and (or) executive bodies of state power in "legislation". "As a result, in the legal literature and in practice, there is a theoretical uncertainty of the nature, place, and role of the principles and provisions of law contained in other forms of the national and international law. The current uncertainty of the law developed from the standpoint of legal positivism has a negative effect on the regulation of public relations" [14].

It appears that criminal law contains not only the provisions of law but also the principles of criminal law. This understanding of criminal law allows solving many theoretical and practical problems of criminal law. Thus, the direct application of the principles of criminal law and criminal proceedings will make it possible to resolve inter-sectoral collisions and contradictions in the qualification of an offence which is due to the low quality of the adopted laws.

For example, at present, it is difficult for a law enforcement officer to correctly qualify a number of crimes given an inter-sectoral conflict of law. In particular, this concerns Art. 327 "Forgery, production or circulation of forged documents, state awards, stamps, seals or letterheads" of the Criminal Code of the Russian Federation and Art. 19.23 "Forgery of documents, stamps, seals or forms, their use, transfer or sale" of the Code of Administrative Offences of the Russian Federation. In this connection, it is not possible to distinguish between counterfeiting, use, and sale of a document, official document, stamp, seal, or letterhead. In this case, it is about an inter-sectoral conflict of legal provisions, and between two regulatory instruments of the same legal force, that is, the choice of the correct qualification of the deed is as difficult as possible for law enforcement. According to Pikurov, this issue should be resolved in favour of qualification as a crime, since "criminal wrongfulness absorbs all other types of wrongfulness and the latter lose their legal significance or significantly apart without merging with each other" [15].

At the same time, this point of view formally emphasises the higher status of the criminal law and does not contain any convincing arguments. At the same time, it should be noted that the problems of qualifying crimes in the absence of certainty in the criminal law provisions became the subject of discussion of the Constitutional Court of the Russian Federation. Thus, in its Resolution No. 8-p of May 27, 2008, the country's highest judicial body emphasised: "Criminal liability can be considered le-gally established and meets the provisions of Art. 55 of the Constitution of the Russian Federation only on the condition that it is adequate to the social danger of the crime and that the criminal law clearly and neatly defines the signs of 
that crime while delimiting it from other illegal, and even more so - from legal acts" [16]. Thus, the Constitutional Court of the Russian Federation directly stipulates that there is nothing criminal and punishable in those penal prohibitions when the law is not clear and incomprehensible to a law enforcement officer.

\section{References}

1. A.P. Simester, Fundamentals of criminal law: responsibility, culpability, and wrongdoing (Oxford University Press, Oxford, 2021).

https://doi.org/10.1093/OSO/9780198853145.001.0001

2. D.E. Robinson, Exploring justice in extreme cases: Criminal law theory and international criminal law, Doctoral thesis (Leiden University, Leiden, 2020). Accessed on: December 20, 2020. [Online]. Available: https://scholarlypublications.universiteitleiden.nl/handle/1887/87892

3. R. Duff, The realm of criminal law (Oxford University Press, Oxford, 2018). https://doi.org/10.1093/oso/9780199570195.001.0001

4. V.A. Nomokonov, Ugolovnaya politika v svete printsipov Novoi kriminologii [Criminal policy in the light of the principles of new criminology], in Ugolovnaya politika i pravoprimenitelnaya praktika: Sb. statei po material. VII Mezhdunarod. nauchno-praktich. konf. (1-2 noyabrya 2019 g., Sankt-Peterburg) [ Criminal policy and law enforcement practice: Collection of articles devoted to the materials of VII International Research-to-Practice Conference (November 1-2, 2019, St. Petersburg)], 67-75 (Asterion, Saint Petersburg, 2019)

5. K.A. Volkov, Ugolovnaya politika i printsipy prava [Criminal policy and principles of law], in Ugolovnaya politika i pravoprimenitelnaya praktika. Sbornik materialov VIIoi Mezhdunarodnoi nauchno-prakticheskoi konferentsii [Criminal policy and law enforcement practice. Collection of files of the 7th International Research-to-Practice Conference], 35-43 (Asterion, Saint Petersburg, 2019)

6. P. Tomlin, Crim. Law Philos. 14(3), 319-333 (2020). https://doi.org/10.1007/s11572019-09511-X

7. B.A. Kurinov, Nauchnye osnovy kvalifikatsii prestuplenii [Scientific basis for the qualification of crimes] (Publishing House of the Moscow University, Moscow, 1984)

8. V.N. Kudryavtsev, Obshchaya teoriya kvalifikatsii prestuplenii [General theory of qualification of crimes] (Yurist, Moscow, 2004)

9. L.D. Gaukhman, Kvalifikatsiya prestuplenii: zakon, teoriya, praktika [Qualification of crimes: law, theory, practice] (Tsenter YurInfoR, Moscow, 2001)

10. T. Kruessmann, Russian Journal of Criminology, 14(5), 745-757 (2020). https://doi.org/10.17150/2500-4255.2020.14(5).745-757

11. E. Herlin-Karnell, General Principles and EU Criminal Law, in K. Zeigler, V. Moreno-Lax, P. Neuvonen (eds.), Handbook on EU general principles (Edward Elgar Publishing, 2020)

12. V.A. Blinnikov, Ugolovnaya politika [Criminal policy], in Ugolovnoe pravo Rossii. Chasti Obshchaya i Osobennaya: Uchebnik [Criminal Law of Russia. General and Special Parts: Textbook] (Prospekt, Moscow, 2015)

13. V.S. Komissarov, N.E. Krylova, I.M. Tyazhkova (eds.), Ugolovnoe pravo Rossiiskoi Federatsii. Obshchaya chast: Uchebnik dlya vuzov [Criminal law of the Russian Federation. General part: Textbook for universities] (Statut, Moscow, 2012) 
14. V.V. Ershov, Pravovoe i individualnoe regulirovanie obshchestvennykh otnoshenii [Legal and individual regulation of public relations] (Russian State University of Justice, Moscow, 2018)

15. N.I. Pikurov, Kvalifikatsiya sledovatelem prestuplenii so smeshannoi protivopravnostyu [Qualification by an investigator of crimes with mixed wrongful-ness] (Higher Investigation School of the Ministry of Internal Affairs of the USSR, Volgograd, 1988)

16. Resolution of the Constitutional Court of the Russian Federation of 27 May 2008 No 8$\mathrm{P}$ "In the Case of Checking the Constitutionality of the Provisions of Part 1 of Art. 188 of the Criminal Code of the Russian Federation in Connection with the Complaint of the Citizen M.A. Aslamazyan", Rossiyskaya Gazeta (June 7, 2008) 